\title{
NITRATE REDUCTASE ACTIVITY AND SPAD READINGS IN LEAF TISSUES OF GUINEA GRASS SUBMITTED TO NITROGEN AND POTASSIUM RATES ${ }^{(1)}$
}

\author{
José Lavres Junior ${ }^{(2)}$, João de Deus Gomes dos Santos Junior ${ }^{(3)}$ \& \\ Francisco Antonio Monteiro ${ }^{(4)}$
}

\begin{abstract}
SUMMARY
Nitrogen and K deficiency are among the most yield limiting factors in Brazilian pastures. The lack of these nutrients can hamper the chlorophyll biosynthesis and $\mathrm{N}$ content in plant tissues. A greenhouse experiment was carried out to evaluate the relationship among $\mathrm{N}$ and $\mathrm{K}$ concentrations, the indirect determination of chlorophyll content (SPAD readings), nitrate reductase activity $\left(\mathrm{RNO}_{3}{ }^{-}\right)$in newly expanded leaf lamina (NL) and the dry matter yield for plant tops of Mombaça grass (Panicum maximum Jacq.). A fractionated $5^{2}$ factorial design was used, with 13 combinations of $\mathrm{N}$ and $\mathrm{K}$ rates in the nutrient solution. The experimental units were arranged in a randomized block design, with four replications. Plants were harvested twice. The first harvest occurred 36 days after seedling transplanting and the second 29 days after the first. Significance occurred for the interaction between the $\mathrm{N}$ and $\mathrm{K}$ rates to SPAD readings and to $\mathrm{RNO}_{3}{ }^{-}$assessment taken on the $\mathrm{NL}$ during the first growth. Besides, $\mathrm{RNO}_{3}{ }^{-}$and $\mathrm{SPAD}$ readings increased only with the NL $\mathrm{N}$ concentration, reaching the highest values of both variables up to about $25 \mathrm{~g} \mathrm{~kg}^{-1}$, but were ratively constant at higher leaf $\mathrm{N}$. Significant relationships either between SPAD readings or $\mathrm{RNO}_{3}{ }^{-}$activity and shoot dry mass weight were also observed. The critical levels of $\mathrm{N}$ concentration in the NL were, respectively, 22 and $17 \mathrm{~g} \mathrm{~kg}^{-1}$ in the first and second harvest. Thus, SPAD instrument and $\mathrm{RNO}_{3}{ }^{-}$ assessment can be used as complementary tools to evaluate the $\mathrm{N}$ status in forage grass.
\end{abstract}

Index terms: chlorophyll, enzymatic assay, nutritional status, grass forage.

\footnotetext{
(1) Received for publication in May 2009 and accepted in April 2010.

(2) Professor, Laboratory of Plant Nutrition, University of São Paulo - USP, Center for Nuclear Energy in Agriculture - CENA. P.O. box 96, Av. Centenário 303, CEP 13400-970 Piracicaba (SP). E-mail: jlavres@cena.usp.br

(3) Doctor Researcher, Embrapa Cerrados. BR 020, km 18, P.O. box 08223, CEP 73310-970 Planaltina (DF). E-mail: jdsantos@cpac.embrapa.br

(4) Full Professor, Departament of Soil Science, "Luiz de Queiroz" College of Agriculture - ESALQ/USP. P.O. box 09, CEP 13418900 Piracicaba (SP). E-mail: famontei@esalq.usp.br
} 


\title{
RESUMO: ATIVIDADE DA REDUTASE DO NITRATO E LEITURAS SPAD EM FOLHAS DO CAPIM-MOMBAÇA SUMETIDO A DOSES DE NITROGÊNIO E POTÁSSIO
}

\begin{abstract}
As deficiências de $N$ e K são um dos principais fatores limitantes para a produção das pastagens brasileiras. Essas deficiências podem comprometer a biossíntese de clorofila e o conteúdo de $N$ nos tecidos vegetais. Realizou-se um experimento com o objetivo de avaliar a relação entre as concentrações de $\mathrm{Ne} K$, a determinação indireta do teor de clorofila, a atividade da $\mathrm{RNO}_{3}^{-}$nas lâminas das duas folhas recém-expandidas $(L R)$ e a produção de massa de matéria seca da parte aérea do capim-mombaça, cultivado em solução nutritiva. Utilizou-se o esquema fatorial $5^{2}$ fracionado, com 13 combinações de $N$ e K. As parcelas foram distribuídas em delineamento experimental de blocos casualizados, com quatro repetições. As plantas foram colhidas duas vezes. Ocorreu significância na interação entre as doses de Ne K para as leituras $S P A D$ e para a avaliação da $R_{N O}{ }^{-}$efetuadas nas $L R$ durante o primeiro crescimento. A atividade da $\mathrm{RNO}_{3}{ }^{-}$e os valores SPAD elevaram-se somente com o aumento da concentração de $N$ nas $L R$, atingindo um patamar próximo a $25 \mathrm{~g} \mathrm{~kg}^{-1}$, permanecendo constante acima desta concentração. Observaram-se relações significativas entre as leituras SPAD, a atividade da $\mathrm{RNO}_{3}{ }^{-}$, a concentração de $\mathrm{N}$ nas $\mathrm{LR}$ e a produção de massa de matéria seca da parte aérea. Os níveis críticos para $N$ nas LR foram de 22 e $17 \mathrm{~g} \mathrm{~kg}^{-1}$, respectivamente para o primeiro e segundo cortes. As avaliações com o clorofilômetro $S P A D$ e da atividade da $\mathrm{RNO}_{3}^{-}$podem ser utilizadas como ferramentas complementares para monitorar o estado nutricional em $\mathrm{N} d o$ capim-mombaça.
\end{abstract}

Termos de indexação: clorofila, avaliação enzimática, estado nutricional, pastagem.

\section{INTRODUCTION}

The importance of $\mathrm{N}$ and $\mathrm{K}$ in mineral nutrition and the tropical grasses yield is noticeable in several studies, since both macronutrients are required in higher amounts. Nitrogen generally represented from 20 to $40 \mathrm{~g} \mathrm{~kg}^{-1}$ of the dry mass of plant tissues (Mengel \& Kirkby, 2001; Malavolta, 2006), being an integral component of many essential compounds to plant growth, such as hormones, aminoacids and proteins. After $\mathrm{N}$, the $\mathrm{K}$ uptake is generally greater than that of any other macronutrient (Marschner, 1995; Epstein $\&$ Bloom, 2005). Once inside the plant, ion K moves readily from older to younger tissue. It performs several functions in the vegetal development, such as in the regulation process of the cell osmotic potential, it is an activator of many enzymes which are involved in the energy transfer, in the build-up of ATP (adenosine-tri-phosphate) which stores the energy needed for $\mathrm{CO}_{2}$ assimilation and the synthesis of sugar, starch, proteins (Marschner, 1995; Mengel \& Kirkby, 2001; Epstein \& Bloom, 2005; Malavolta, 2006).

Traditionally whole plant shoots are sampled for forage nutritional diagnosis, however, attempts have been made to collect and analyze parts of the forage plant tops (Batista \& Monteiro, 2007). Additional N applied to perennial ryegrass was primarily used to increase total-N content in leaves, which were the prefered N storage organs (Gislum et al., 2003). On the other hand, the newly expanded lamina leaf (NL) - formerly known as recently expanded lamina has been utilized as morphological component of plant tops, appropriate for the evaluation of the nutritional status, mainly for $\mathrm{N}$ and sulphur (Mattos \& Monteiro, 2003; Batista \& Monteiro, 2007; Lavres Jr. et al., 2008). In addition, measurements of the greenness or the relative chlorophyll concentration of leaves using the chlorophyll meter (SPAD-502), and the nitrate reductase activity $\left(\mathrm{RNO}_{3}{ }^{-}\right)$assessment have been used as an evaluation tool of the $\mathrm{N}$ nutritional status in tropical grasses (Lavres Jr. \& Monteiro, 2006), since $\mathrm{N}$ is part of the chlorophyll pigment structure and is involved in $\mathrm{RNO}_{3}{ }^{-}$activation (Mengel \& Kirkby, 2001). However, results in the literature related to such evaluations of tropical grasses subjected to $\mathrm{N}$ and $\mathrm{K}$ supply are rather scarce.

Thus, the development of approaches such as chlorophyll meter readings, enzyme activity assessment (e.g., nitrate reductase, glutamine synthetase) (Reis et al., 2009a,b) as well as remote sensing techniques (Zhu et al., 2007; Silva Jr. et al., 2008, Stroppiana et al., 2009) are being more useful for plant nutritional diagnosis and then the prediction of fertilizer requirements in crop fields - specifically related to $\mathrm{N}$ supply. Furthermore, it might guide in the early evaluation of grasses nutritional status as well as the yield, and then the fertilization management.

The objectives of this study were to evaluate the $\mathrm{N}$ and $\mathrm{K}$ concentrations on the newly expanded lamina leaf (NL), the indirect determination of chlorophyll content (SPAD readings) and nitrate reductase activity 
$\left(\mathrm{RNO}_{3}{ }^{-}\right)$in the NL of Panicum maximum Jacq. cultivar 'Mombaça' as related to the $\mathrm{N}$ and $\mathrm{K}$ rates and then evaluate the relationship between SPAD or $\mathrm{RNO}_{3}{ }^{-}$and dry matter yield for plant tops.

\section{MATERIAL AND METHODS}

The experiment was carried out in a greenhouse at University of São Paulo - "Luiz de Queiroz" College of Agriculture, in Piracicaba, São Paulo, Brazil. Guinea grass (Panicum maximum Jacq. cv. Mombaça) was grown in the period from November 2000 to February 2001. The average maximum/minimum temperatures during the experimental period were $40.2 \pm 0.57^{\circ} \mathrm{C} /$ $22.9 \pm 0.29^{\circ} \mathrm{C}$.

Guinea grass seeds were sown in early November in plastic trays containing washed sand and were periodically watered with deionized water. When the seedlings were about four centimeters tall, 12 days after sowing, they were transplanted to $3.6 \mathrm{~L}$ plastic pots (diameter $17 \mathrm{~cm}, 15$ plants per pot), filled with ground quartz. One day after transplantation, one liter of diluted nutrient solution was supplied at $25 \%$ of the concentration corresponding to each $\mathrm{N}$ and $\mathrm{K}$ combination, prepared by modifying a complete nutritive solution (Sarruge, 1975), to avoid salt stress. Combinations of $\mathrm{N}$ and $\mathrm{K}$ rates were tested in nutrient solutions. Five N rates $(28 ; 112 ; 210 ; 336$ and $\left.462 \mathrm{mg} \mathrm{L}^{-1}\right)$ and five $\mathrm{K}$ rates $(19.5 ; 117 ; 234 ; 312$ and $429 \mathrm{mg} \mathrm{L}^{-1}$ ) were combined in a fractionated $5^{2}$ factorial setup based on Littell \& Mott (1975). The resulting 13 combinations were: $28 / 19.5 ; 28 / 234 ; 28$ / $429 ; 112 / 117 ; 112 / 312 ; 210 / 19.5 ; 210 / 234 ; 210 / 429$; $336 / 117 ; 336 / 312 ; 462 / 19.5 ; 462 / 234$ and $462 /$ $429 \mathrm{mg} \mathrm{L}^{-1}$. All nutrient solutions were prepared by modifying the complete solution of Sarruge (1975). The experiment was performed in a randomized block design, with four replications, keeping constant the $\mathrm{N}-\mathrm{NO}_{3}{ }^{-}: \mathrm{N}-\mathrm{NH}_{4}{ }^{+}$at $1.8\left(64.4 \%\right.$ of $\mathrm{NO}_{3}{ }^{-}$and $35.6 \%$ of $\mathrm{NH}_{4}{ }^{+}$). The $\mathrm{N}$ and $\mathrm{K}$ rates were based on those from Abreu \& Monteiro (1999) and Mattos \& Monteiro (1998), respectively.

Initially, the solutions remained in the pots during the day and at night and were circulated through the silica four times a day for one week. Thereafter, the solutions were drained at night and supplied during the day, when they were circulated three times a day. Periodic thinnings were conducted until five plants per pot remained. The solutions containing the effective $\mathrm{N}$ and $\mathrm{K}$ concentrations were used after the fourth day from seedling transplanting, and were renewed every 14 days. The pots were rearranged within each block every three days.

The plants were cultivated in two growing periods. The first harvest was done 36 days after the seedlings were transplanted, at $3 \mathrm{~cm}$ from the plants' root collar, while the second harvest (plants cut at the surface of the substrate), occurred 29 days after the first. Immediately after the second harvest the roots were separated from the silica and washed in running water and deionized water, and recovered with two 0.25 and $1.00 \mathrm{~mm}$ sieves. At each harvest, three leaf tissues were collected from plant shoots: emergent leaves (EL, leaves not fully expanded); newly expanded lamina leaf (NL, lamina of the two most recently expanded leaves); mature leaf lamina (ML, lamina of all other expanded leaves).

The plant material collected in both harvests was dried in a forced air circulation oven, at a temperature of $65{ }^{\circ} \mathrm{C}$ for $72 \mathrm{~h}$, and was later weighed with a precision balance. Evaluation with the use of the chlorophyll meter and the enzymatic activity of the nitrate reductase were carried out on newly expanded lamina leaf (NL), which corresponded to the lamina of the two most recently expanded leaves with visible ligule. Nitrogen (micro Kjeldahl method) and K (flame atomic absorption spectrometry) concentrations were determined according to the methodology presented by Malavolta et al. (1997).

The SPAD value was determined using the Chlorophyll Meter SPAD-502 (Soil-Plant Analysis Development, Minolta, 1989). This value was obtained non-destructively on the NL (newly expanded lamina leaf from the top of the shoot). Determinations were made one day before the cuts, on the $35^{\text {th }}$ and $28^{\text {th }}$ days, respectively, in the first and second plant growth periods, when ten readings were taken on plants from each pot with the apparatus sensor at the one-third portion in the middle of the lamina, taking care to avoid the midrib (Lavres Jr. \& Monteiro, 2006; Batista \& Monteiro, 2007).

The activity of nitrate reductase was determined in accordance with the method described by Mulder et al. (1959). On the $32^{\text {nd }}$ and $16^{\text {th }}$ days of the first and second growth period of the Mombaça grass, respectively, samples were taken of the middle third of the lamina of the two most recently expanded leaves (NL). Before sampling the lamina, the plants were placed in growing chambers and left air-open for two hours at a constant temperature of around $27^{\circ} \mathrm{C}$, in order to avoid external interference in the enzyme activity at different $\mathrm{N}$ and $\mathrm{K}$ rates.

Samples of fresh leaf tissue were collected and stored in plastic bags and transported to the laboratory on ice, and then, rinsed with deionized water. Afterwards, $200 \mathrm{mg}$ of fresh green tissue cut in discs, were transferred to essay tubes containing $3 \mathrm{~mL}$ of phosphate buffer solution $\mathrm{pH} 7.4\left(50 \mathrm{mmol} \mathrm{L}^{-1}+\right.$ $\mathrm{KNO}_{3} 200 \mathrm{mmol} \mathrm{L}^{-1}$ ). After that, the essay tubes were incubated in a water bath at $33^{\circ} \mathrm{C}$ for two hours and wrapped in aluminum sheet to protect them from light. The reaction was stopped by adding $1 \mathrm{~mL}$ of $1 \%$ sulfanilamide in $2 \mathrm{~mol} \mathrm{~L}^{-1} \mathrm{HCl}$ solution and after that, $1 \mathrm{~mL}$ of $0.05 \%$ naphtylenediamine solution was added. The nitrite $\left(\mathrm{NO}_{2}^{-}\right)$produced was measured in a spectrophotometer at $560 \mathrm{~nm}$, using nitrite standard 
calibration curve. The enzyme activity was directly related to the amount of $\mathrm{NO}_{2}{ }^{-}$determined and the results were expressed in $\mu \mathrm{mol} \mathrm{h}^{-1} \mathrm{~g}^{-1} \mathrm{NO}_{2}^{-}$fresh matter.

The results were submitted to statistical analysis using the software SAS System for Windows 6.11 (SAS, 1996). The analysis of variance (ANOVA) was carried out, and based on the level of significance in the $\mathrm{F}$ test $(\mathrm{p}<0.05)$ for the $\mathrm{N}$ and $\mathrm{K}$ rates, a polynomial regression (response surface) was calculated or a regression was calculated for the firstand second-degree compounds, through the GLM (general linear model) procedure. Thus, it was considered the polynomial regression model with the highest relationship coefficient $(\mathrm{r})$ and significance for the studied relationships.

\section{RESULTS AND DISCUSSION}

The 'Mombaça' grass presented the visual symptoms of $\mathrm{N}$ and $\mathrm{K}$ deficiency six days after the start of the treatments. The plants were small, with thin and stunted tillers. The older laminas were light green with chlorosis and then necrotic margins. These anomalies were observed in all plants kept either at the lowest $\mathrm{N}$ or $\mathrm{K}$ rates. In addition, $\mathrm{N}$ deficiencyinduced leaf senescence was monitored by changes in the leaf chlorophyll content, as indicated by SPAD readings (close to $28 \mathrm{SPAD}$ units), since SPAD values are significantly correlated with chlorophyll and leaf N (Malavolta et al., 2004; Wiedenfeld et al., 2009; Reis et al., 2009b). Similar effects were also observed in $P$. maximum 'Aruana' grass grown in the same nutrient solution with $\mathrm{N}$ rate of $14 \mathrm{mg} \mathrm{L}^{-1}$ (Lavres Jr. \& Monteiro, 2006).

There was a significant $(p<0.01)$ correlation of the interaction between the $\mathrm{N}$ and $\mathrm{K}$ rates to SPAD readings taken on the newly expanded leaf lamina (NL) during the first growth of the plants (Figure 1a). The estimated values of the chlorophyll concentration, in SPAD values, were well-adjusted to the polynomial regression model. The $\mathrm{N}$ and $\mathrm{K}$ rates necessary for the maximum values were $733 \mathrm{mg} \mathrm{L}^{-1}$ and $491 \mathrm{mg} \mathrm{L}^{-1}$, respectively, at a 1.50:1.00 ratio between the $\mathrm{N}$ and $\mathrm{K}$ concentrations in the nutrient solution. There was always a need for proper balance between these two nutrients to sustain the chlorophyll content and achieve an optimum photosynthesis rate in the leaves, to accumulate biomass and consequently attain maximum shoot dry matter yield (Lemaire et al., 2007; Giunta et al., 2009).

At the lowest $\mathrm{N}$ and $\mathrm{K}$ combination, the SPAD value was $10.5 \%$ higher than that obtained when $\mathrm{N}$ and $\mathrm{K}$ were supplied at 28 and $429 \mathrm{mg} \mathrm{L}^{-1}$, respectively, probably due to $\mathrm{N}$ and $\mathrm{K}$ nutritional imbalance in the chlorophyll pigment biosynthesis. At concentrations of $210 \mathrm{mg} \mathrm{L}^{-1} \mathrm{~N}$ and $234 \mathrm{mg} \mathrm{L}^{-1} \mathrm{~K}$ (which are the adequate levels for Sarruge's solution), the average value corresponded to $75 \%$ of the SPAD units achieved at the highest $\mathrm{N}$ and $\mathrm{K}$ combination.

On the other hand, the chlorophyll values during the second growth varied significantly $(p<0.01)$ due to the $\mathrm{N}$ rates. The data in this case best fit a quadratic regression model (Figure 1b). This can perhaps be explained by the fact that the chlorophyll meter reading indirectly expresses the chlorophyll concentration in the plant tissue and since $\mathrm{N}$ is a component of the chlorophyll molecule, the $\mathrm{N}$ shoot content is positively correlated to the SPAD values. This has already been pointed out in several studies. Furthermore, in the first growth period of the plants this interaction was significant probably due to the role of $\mathrm{K}$ in several biochemical and enzymatic reactions that limit the synthesis of aminoacids, proteins and other organic compounds such as the chlorophyll (Epstein \& Bloom, 2005; Malavolta, 2006).

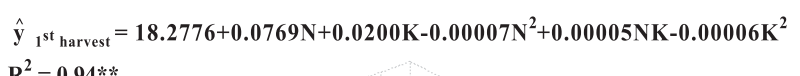
$\mathbf{R}^{2}=0.94 * *$
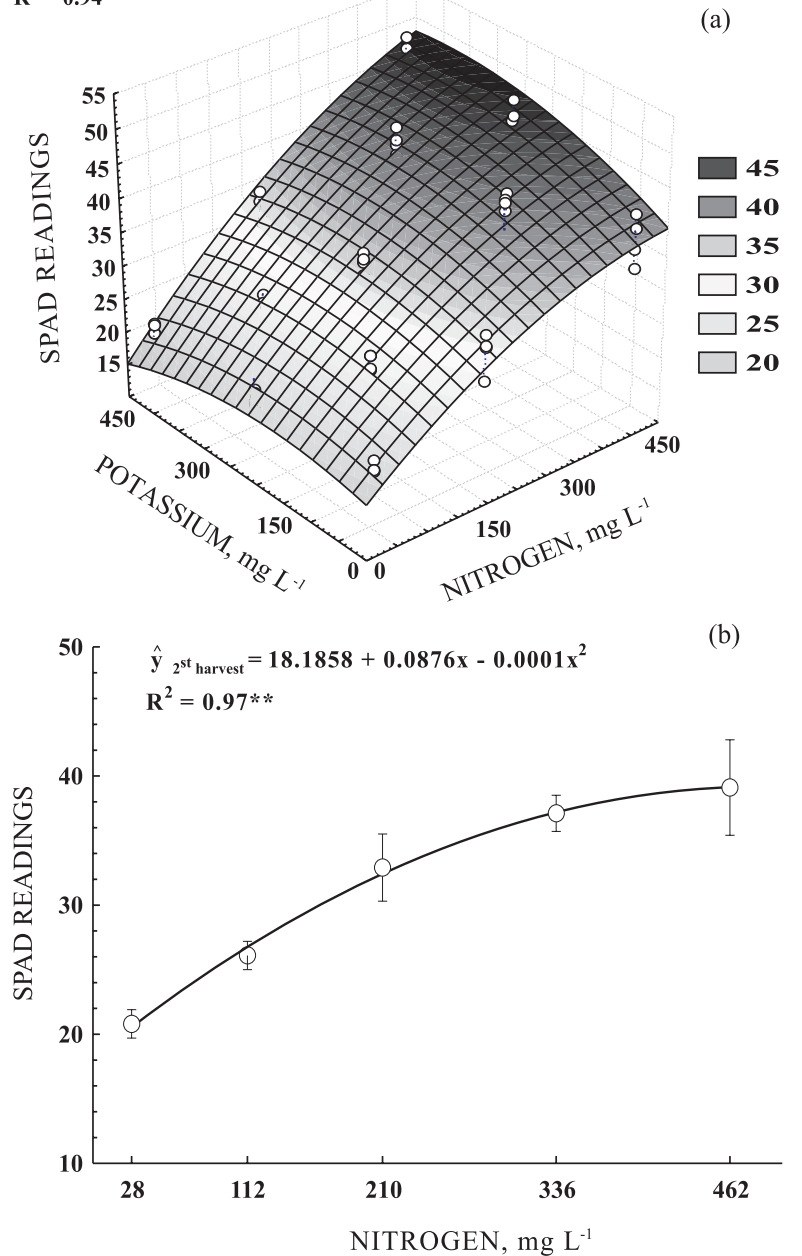

Figure 1. SPAD readings taken on the newly expanded lamina leaf (NL) of 'Mombaça' grass, in the first (a) and second (b) growth, as related to $\mathrm{N}$ and $\mathrm{K}$ or $\mathrm{N}$ rates. 
For the second plant harvest, the average chlorophyll content ranged from 20.6 to 39.0 SPAD units, corresponding to the lowest and the highest $\mathrm{N}$ rate, respectively. The maximum SPAD reading occurred when the nutrient was supplied at $438 \mathrm{mg} \mathrm{L}^{-1}$. The range of this characteristic in both harvests can be explained also by the variations in the growth rates and the beginning of leaf senescence. Generally in the second period of growth of these plants, the leaf senescence flux is more accentuated than in the first growth, and then presents negative $\mathrm{C}$ partition (Hay $\&$ Walker, 1989). This effect has already been noted by Lavres Jr. \& Monteiro (2006) for 'Aruana' grass, also a cultivar of Panicum maximum.

In addition to the SPAD chlorophyll values, the nitrate reductase activity $\left(\mathrm{RNO}_{3}^{-}\right)$was different between the first and second growth of the 'Mombaça' grass. During the first growth, the interaction between $\mathrm{N}$ and $\mathrm{K}$ rates was significant $(\mathrm{p}<0.05)$ in the enzyme assay (Figure $2 \mathrm{a}$ ). In the second growth, the enzymatic activity was significant only for the $\mathrm{N}$ rates, and was best adjusted to the exponential regression model shown in figure $2 b$.

For any $\mathrm{N}$ rates supplied in the nutrient solution combined with the lowest K level, there was practically no variation of the $\mathrm{RNO}_{3}{ }^{-}$activity (Figure 2a), indicating the importance of the $\mathrm{K}$ in the enzymatic activation process. We also found that at the highest $\mathrm{K}$ rate combined with the lowest $\mathrm{N}$ rate in the solution (28N/429K), the $\mathrm{RNO}_{3}{ }^{-}$was limited due to the very low $\mathrm{N}$ rate, since the activity of this enzyme, besides other factors (such as luminosity and temperature) is induced by the $\mathrm{N}^{-\mathrm{NO}_{3}}$ - concentration in the substrate (Mengel \& Kirkby, 2001). According to the polynomial regression equation, the maximum enzyme activity was reached by supplying the highest $\mathrm{N}$ and $\mathrm{K}$ rates in the nutrient solution ( $462 \mathrm{~N} / 429 \mathrm{~K})$.

With respect to the importance of $\mathrm{K}$ for $\mathrm{RNO}_{3}{ }^{-}$, Pflüger \& Wiedemann (1977) reported that K probably participates in the activation of this enzyme and that this cation is needed for synthesis of nitrate reductase. Several studies have shown the significance of $\mathrm{K}$ nutrition and its effect on modulating the $\mathrm{RNO}_{3}{ }^{-}$in various plants, such as mustard (Umar \& Bansal, 1995), soybean (Anuradha \& Sarma, 1995), tea (Venkatesan \& Ganapathy, 2004), and palisadegrass (Brachiaria brizantha cv. Marandu) (Megda, 2009). However, more studies of this type are needed with tropical forage grasses.

For the second grown of the plants (Figure 2b), the $\mathrm{RNO}_{3}{ }^{-}$increased sharply with increasing $\mathrm{N}$ rates at $\mathrm{RNO}_{3}{ }^{-}$values between 0.032 to $0.055 \mu \mathrm{mol} \mathrm{g}^{-1} \mathrm{~h}^{-1}$ $\mathrm{NO}_{2}{ }^{-}$in FM. Above those N-rates, $\mathrm{RNO}_{3}{ }^{-}$did not increase appreciably in relation to $\mathrm{N}$ concentration in the nutrient solution. On the other hand, a possible cause of the absence of a significant $\mathrm{K}$ effect on this biochemical attribute could be due to the luxury consumption of this nutrient by the plants during first growth, which was effective for the plants to attain
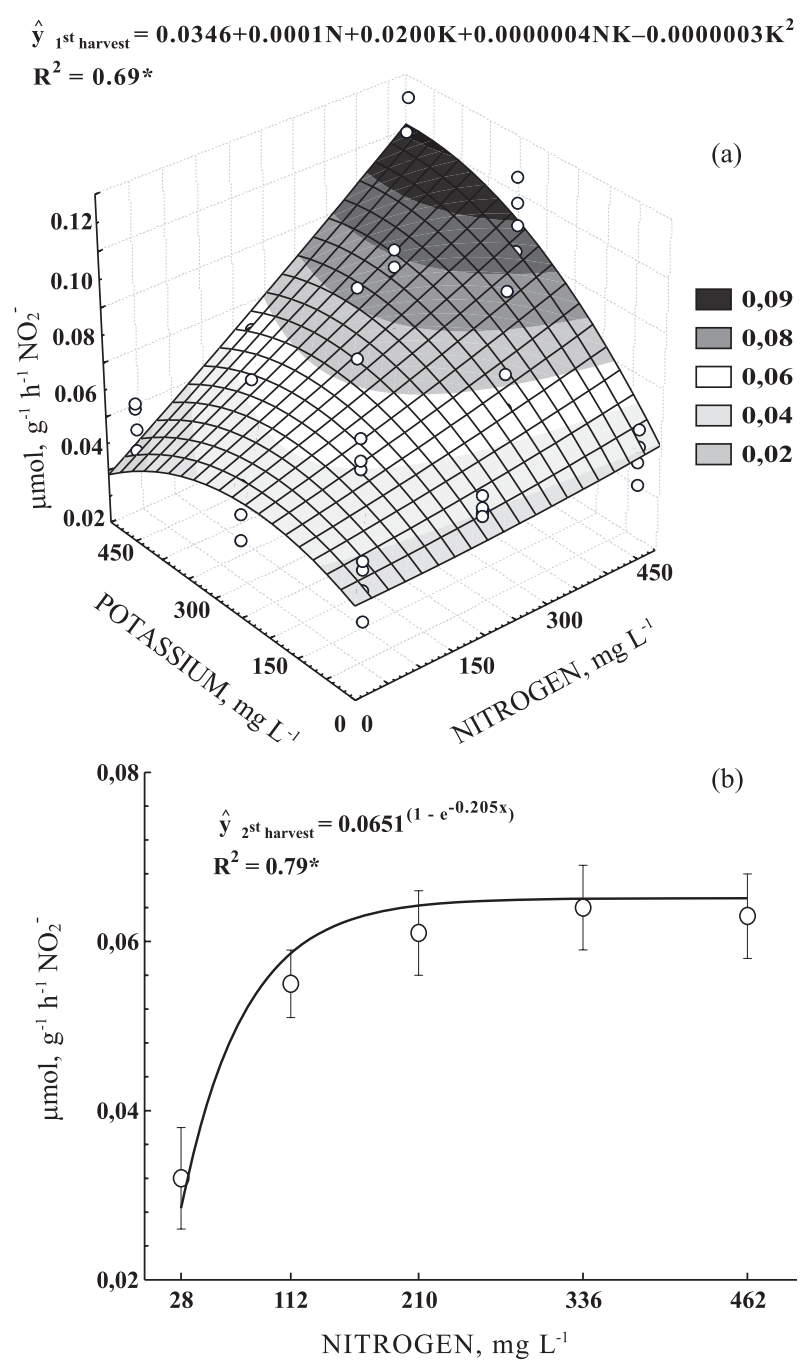

Figure 2. Nitrate reductase activity taken on the newly expanded lamina leaf (NL) of 'Mombaça' grass, in the first (a) and second (b) growth, as related to $\mathrm{N}$ and $\mathrm{K}$ or $\mathrm{N}$ rates.

their K nutritional requirement. However, K has been reported to be involved either in early $\mathrm{N}$ assimilation or the final steps of $\mathrm{N}$ metabolism, i.e., incorporation of mineral $\mathrm{N}$, especially in nitrate reduction (Venkatesan \& Ganapathy, 2004). We should notice that $\mathrm{N}$ deficiency has been pointed out as the main cause of low dry mass yield or delay some biochemical roles in plant metabolism. In fact, the efficiency of the $\mathrm{N}$ use can be influenced by the plant $\mathrm{K}$ nutritional status.

The N concentration in the NL of 'Mombaça' grass in both harvests was significantly influenced by the $\mathrm{N}$ and $\mathrm{K}$ combination (Figure 3a,b). On the other hand, the $\mathrm{K}$ concentration in these leaves was only influenced by the $\mathrm{K}$ rates (Figure 4). Differences in $\mathrm{N}$ concentration were not found at either the smallest (28/19.5) or highest (462/429) $\mathrm{N}$ and K combinations, characterizing, respectively, the concentration and 
dilution effects. Furthermore, the highest N concentration in these leaves was obtained with $\mathrm{N}$ and K rates, respectively, of 462 and $19.5 \mathrm{mg} \mathrm{L}^{-1}$, whereas the smallest value was found for at $\mathrm{N}$ rate of $28 \mathrm{mg} \mathrm{L}^{-1}$ associated with $234 \mathrm{mg} \mathrm{L}^{-1} \mathrm{~K}$. Also, the $\mathrm{K}$ concentration in the newly expanded leaf lamina (NL) ranged from 3.9 to $14.1 \mathrm{~g} \mathrm{~kg}^{-1}$ and from 2.7 to $13.9 \mathrm{~g} \mathrm{~kg}^{-1}$ in the first and second harvests, respectively (Figure 4). However, these values are slightly below those for the new shoot $\mathrm{K}$ concentration (15 to $30 \mathrm{~g} \mathrm{~kg}^{-1}$ ) reported by Werner et al. (1996) for P. maximum 'Colonião'. Nevertheless, the shoot K concentration can be smaller than those of the new leaves or new tissues, once inside the plant $\mathrm{K}$ moves readily from older to younger tissue (Marschner, 1995). In addition, another possible cause of this effect could be due to the wide range of K-requirements among

$\hat{y}_{1{ }^{\text {st }}}$ arrest
$R^{2}=0.89^{*}$

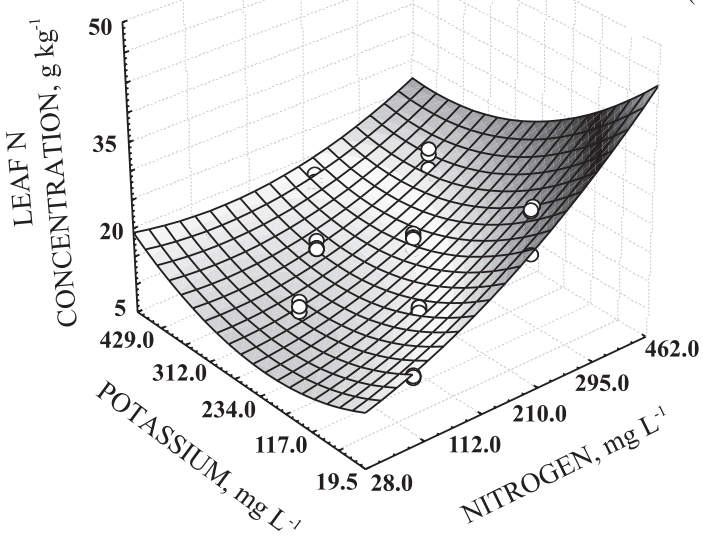

$\hat{y}_{2^{\text {st }} \text { harvest }}=11.3681+0.05413 \mathrm{~N}-0.07318 \mathrm{~K}-0.000124 \mathrm{NK}+0.000170 \mathrm{~K}^{2}$ $\mathbf{R}^{2}=\mathbf{0 . 8 3}$ *

(b)

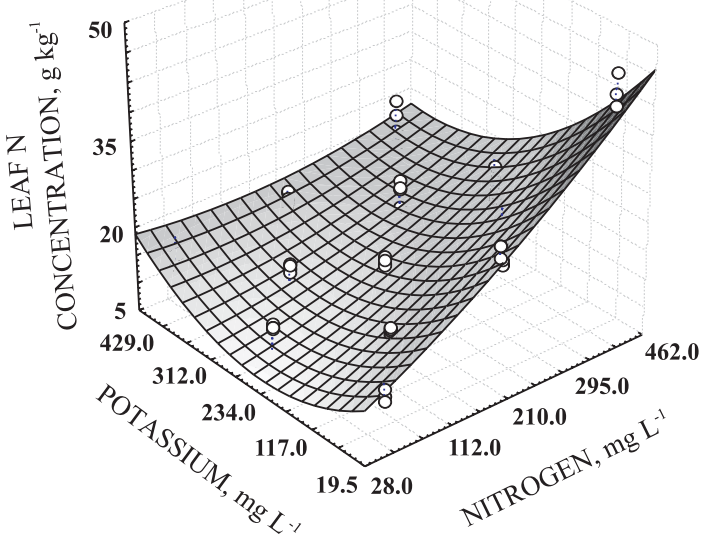

Figure 3. Leaf nitrogen concentration in the newly expanded leaf lamina (NL) of 'Mombaça' grass, in the first (a) and second (b) growths, related to $\mathrm{N}$ and $\mathrm{K}$ rates.

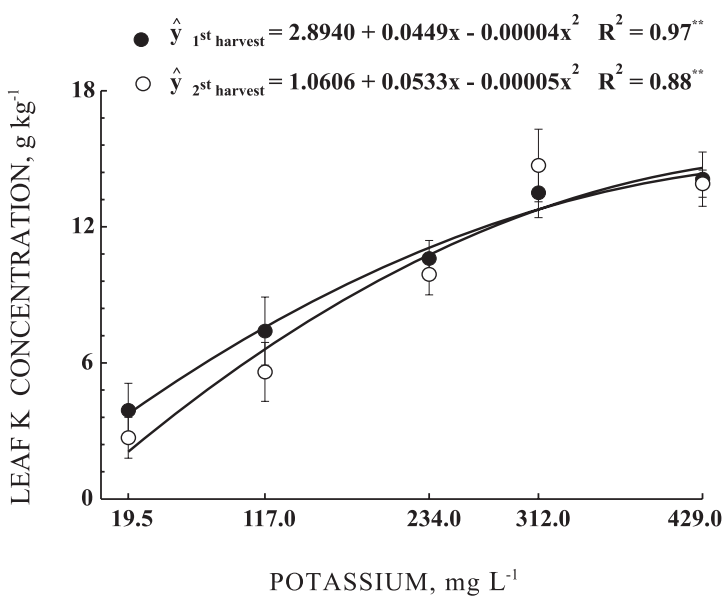

Figure 4. Leaf potassium concentration in the newly expanded leaf lamina (NL) of 'Mombaça' grass, in the first $(O)$ and second $(O)$ growths, related to $\mathrm{K}$ rates.

the genotypes/cultivars within species (Daliparthy et al., 1994), or due to sampling period to plant harvest.

In the first growth, the nitrate reductase activity $\left(\mathrm{RNO}_{3}{ }^{-}\right)$and SPAD values increased only with the newly expanded leaf lamina (NL) N concentrations, reaching the highest values of both variables up to about $25 \mathrm{~g} \mathrm{~kg}^{-1}$, which is considered adequate to the new shoot of $P$. maximum (Werner et al., 1996). But it was relatively constant at higher leaf N levels. This leaf $\mathrm{N}$ concentration was related to the following mean values for $\mathrm{RNO}_{3}{ }^{-}$and SPAD values, respectively: $0.1 \mu \mathrm{mol} \mathrm{g}-1 \mathrm{~h}^{-1} \mathrm{NO}_{2}^{-}$in $\mathrm{FM}$; and 45 units (Figure 5). Figure 5 also shows the low $\mathrm{RNO}_{3}$ - activity at both the lowest and highest $\mathrm{N}$ leaf concentrations, as indicated by the three plots (arrow), which are the three replicates for a $\mathrm{K}$ rate of $19.5 \mathrm{mg} \mathrm{L}^{-1}$. This shows the importance of the $\mathrm{K}$ for $\mathrm{RNO}_{3}{ }^{-}$activation, even though these relationships were not significant to $\mathrm{K}$ leaf concentrations. In addition, the same effects of the relationship between $\mathrm{RNO}_{3}$ and leaf $\mathrm{N}$ concentration or SPAD readings and leaf $\mathrm{N}$ concentration were also found for the second growth of the Guinea grass (Figure 6). For both plant growth periods, these relationships between newly expanded leaf lamina chlorophyll content and newly expanded leaf lamina $\mathrm{N}$ concentration provides some measure of the plant's N status. There was a wide range of values for chlorophyll content around the $\mathrm{N}$ critical level, but above the critical level, the SPAD values were relatively constant and newly expanded leaf lamina $\mathrm{N}$ increased rapidly (Figures 5 and 6).

The results indicate that leaf $\mathrm{N}$ content above the critical level did not result in greater chlorophyll production, since the chlorophyll content reaches a point called photosynthetic maturity, after which it remains unchanged even with increasing $\mathrm{N}$ concentration in the tissue. This $\mathrm{N}$ may be associated either with other organic compounds or as $\mathrm{N}^{-\mathrm{NO}_{3}}{ }^{-}$ (Costa et al., 2001). These phenomena have been 
observed in other tropical forage grasses and suggest the accuracy of these measurements in the early assessment of forage N-nutritional status, as pointed out by Lavres Jr. \& Monteiro (2006) and Batista \& Monteiro (2007).

There was a significant relationship both between SPAD readings and $\mathrm{RNO}_{3}{ }^{-}$activity and dry matter yield of plant tops, as shown in figures 7 and 8 . The higher dry matter yield observed in the second harvest, associated with same SPAD reading from the first growth, could have been due mainly to the number of expanded green leaves and higher N uptake during the second growth, as well as the possibility of reduced senescence of these leaves, which may contribute to a longer leaf life. In other words, greater photosynthetic capacity for longer periods must be due to limited $\mathrm{N}$ redistribution toward younger tissues. In situations as in this study, the SPAD readings and

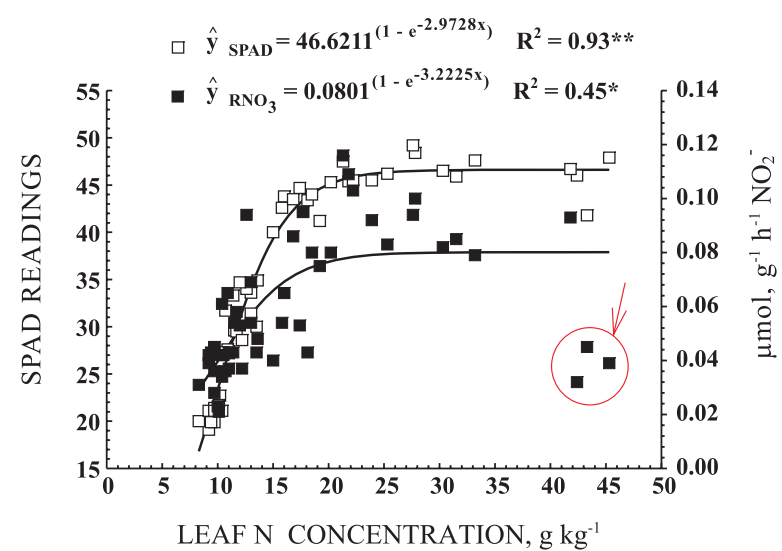

Figure 5. Relationship among SPAD readings ( $\square$ ), leaf $\mathrm{N}$ concentration and nitrate reductase activity $(\square)$ taken on the newly expanded lamina leaf (NL), in the first growth. The three plots (arrow) are related to $\mathrm{N}$ and $\mathrm{K}$ combination of $429 \mathrm{~N} /$ 19.5K.

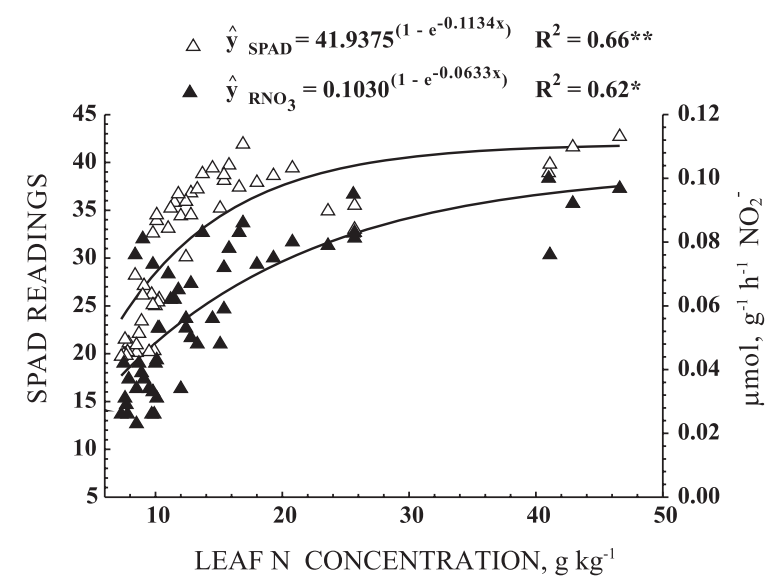

Figure 6. Relationship among $\mathrm{SPAD}$ readings $(\triangle)$, leaf $\mathrm{N}$ concentration and nitrate reductase activity (A) taken on the newly expanded lamina leaf $(\mathrm{NL})$, in the second growth.

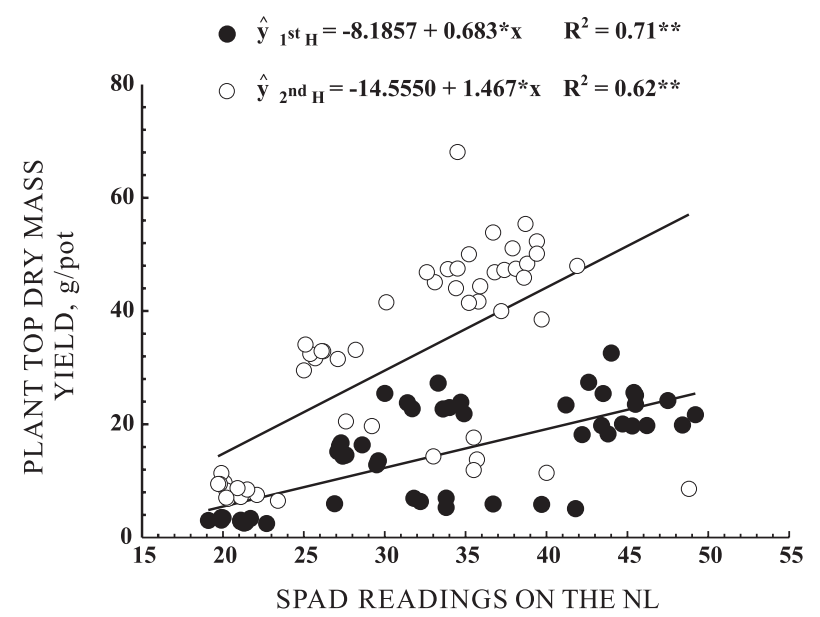

Figure 7. Relationship between plant top dry mass yield and SPAD readings taken on the newly expanded lamina leaf (NL), in the first (O) and second (O) growth of the 'Mombaça' grass.

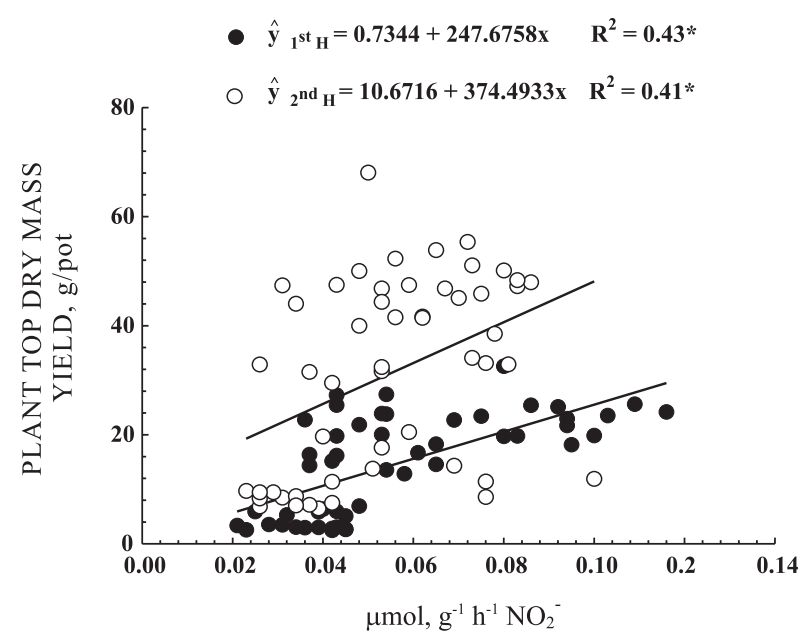

Figure 8. Relationship between plant top dry mass yield and nitrate reductase activity taken on the newly expanded lamina leaf (NL), in the first (O) and second (O) growth of the 'Mombaça' grass.

$\mathrm{RNO}_{3}{ }^{-}$activity taken before plant harvests are suitable predictors both for shoot $\mathrm{N}$ content and for forage yield. Thus, the SPAD method is adequate for rapid diagnosis and decision making because of the sensitivity of its readings shortly after $\mathrm{N}$ supply.

The significant relationship between SPAD readings and plant top dry matter yield (Figure 7) represents an alternative for monitoring and predicting forage $\mathrm{N}$-nutritional status, because $\mathrm{N}$ is a major component of the chlorophyll molecule (Marschner, 1995; Mengel \& Kirkby, 2001) and is also involved in nitrate reductase activity. Moreover, the chlorophyll content in leaves correlates positively with that in the whole plant. This relation is mainly because 50 to $70 \%$ of the total $\mathrm{N}$ of leaves is closely 
associated with the chloroplast (Chapman \& Barreto, 1997). These observations mirror those of Gaborcik (1996), who confirmed a close relation between SPAD values and dry matter production in some perennial and temporary grasses from Slovakia.

There was not a significant $(p>0.05)$ relationship between the dry mass yield for plant tops and newly expanded leaf lamina K concentrations. For this reason, it was not possible to fit a quadratic regression model concerning this relationship, and finally figure out the K leaf critical level. On the other hand, there was a significant $(p<0.01)$ relationship between the dry mass yield for plant tops and newly expanded leaf lamina $\mathrm{N}$ concentrations, for the first and second growths of 'Mombaça' grass. Besides, the shoot dry weight increased sharply with increasing $\mathrm{N}$ concentration of the newly expanded leaf lamina at leaf $\mathrm{N}$ values between 10 to $15 \mathrm{~g} \mathrm{~kg}^{-1}$ (Figure 9), corresponding to deficiency status. Above that concentration, plant dry weight gain increased appreciably in relation to leaf $\mathrm{N}$. The fitting of the polynomial function allowed calculating a leaf critical N-level corresponding to a $90 \%$ maximum yield of 22 and $17 \mathrm{~g} \mathrm{~kg}^{-1}$, respectively, in the first and second harvests. These values are lower than those cited by Lavres Jr. Monteiro (2006) for P. maximum 'Aruana'. Together these findings show the N-requirement wide range among the genotypes/cultivars within species.

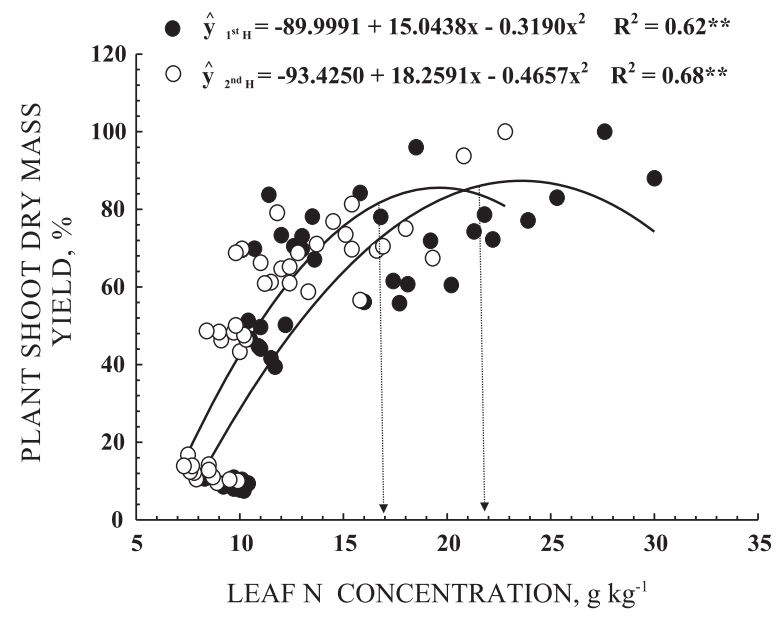

Figure 9. Relationship between newly expanded lamina leaf (NL) $N$ concentration and plant top dry mass yield, in the first $(O)$ and second $(O)$ growth of the 'Mombaça' grass. Solid lines indicate the leaf $\mathrm{N}$ concentration corresponding to $90 \%$ of maximum yield.

\section{CONCLUSIONS}

1. Nitrate reductase activity and SPAD readings taken on the newly expanded lamina leaf (NL) of 'Mombaça' grass, which is considering the plant part used to nutritional diagnose, might constitute an additional tool to forage $\mathrm{N}$ evaluations and the early prediction of nutrient requirement.

2. Leaf nitrate reductase and SPAD readings tend to increase as leaf $\mathrm{N}$ increases and these variables maintain a positive and significant relationship with 'Mombaça' grass yield.

3 . The early assay of chlorophyll content as well as the plants' $\mathrm{N}$ status and their relationships could help in the early assessment of forage grass $\mathrm{N}$ nutritional status as well as its yield and finally to the management of fertilization.

4. The $\mathrm{N}$ efficiency use by Mombaça grass is influenced by its K nutritional status.

\section{ACKNOWLEDGEMENTS}

We thank CNPq for the research grant of F.A.Monteiro and FAPESP for the postdoctoral fellowship (Ref. Proc. 07/58406-1) given to J.Lavres Jr.

\section{LITERATURE CITED}

ABREU, J.B.R. \& MONTEIRO, F.A. Produção e nutrição do capim-Marandu em função de adubação nitrogenada e estádios de crescimento. B. Ind. Animal, 56:137-146, 1999.

ANURADHA, K. \& SARMA, P.S. Effect of moisture stress and applied potassium on yield and biochemical parameters of soybean in vertisols. J. Oilseed. Res., 12:275-278, 1995.

BATISTA, K. \& MONTEIRO, F.A. Nitrogen and sulphur in marandu grass: Relationship between supply and concentration in leaf tissues. Sci. Agric., 64:44-51, 2007.

CHAPMAN, S.C. \& BARRETO, H.J. Using a chlorophyll meter to estimate specific leaf nitrogen of tropical maize during vegetative growth. Agron. J., 89:557-562, 1997.

DALIPARTHY, J.; BARKER, A.V. \& MONDAL, S.S. Potassium fractions with other nutrients in crops - A review focusing on the tropics. J. Plant. Nutr., 17:1859-1886, 1994.

EPSTEIN, E. \& BLOOM, A.J. Mineral nutrition of plants: Principles and perspectives. 2.ed. Sunderland, Sinauer, 2005. 400p.

GABORCIK, N. Chlorophyll concentration (SPAD) in leaves of dominant species of grasses as indicator of grassland production. Rostl. Vyroba, 42:478-480, 1996.

GISLUM, R.; WOLLENWEBER, B.; BOELT, B. \& JENSEN, E.S. Uptake and distribution of nitrogen in perennial ryegrass: Effect of additional applications at vegetative growth. J. Plant. Nutr., 26:2375-2389, 2003.

GIUNTA, F.; PRUNEDDU, G. \& MOTZO, R. Radiation interception and biomass and nitrogen accumulation in different cereal and grain legume species. Field Crop. Res., 110:76-84, 2009. 
HAY, R.K.M. \& WALKER, A.J. An introduction to the physiology of crop yield. London, Longman Scientific and Technical, 1989. 292p.

LAVRES JR., J. \& MONTEIRO, F.A. Diagnose nutricional de nitrogênio no capim-aruana em condições controladas. R. Bras. Ci. Solo, 30:829-837, 2006.

LAVRES JR., J.; MONTEIRO, F.A. \& SCHIAVUZZO, P.F. Concentração de enxofre, valor SPAD e produção do capim-Marandu em resposta ao enxofre. R. Bras. Ci. Agr., 3:225-231, 2008.

LEMAIRE, G.; van OOSTEROM, E.; SHEEHY, J.; JEUFFROY, M.H.; MASSIGNAM, A. \& ROSSATO, L. Is crop N demand more closely related to dry matter accumulation or leaf area expansion during vegetative growth? Field Crop. Res., 100:91-106, 2007.

LITTELL, R.C. \& MOTT, G.O. Computer assisted design and analysis of response surface experiments in agronomy. Soil Crop Sci. Soc. Fla. Proc., 34:94-97, 1975.

MALAVOLTA, E. Manual de nutrição mineral de plantas. São Paulo, Agronômica Ceres, 2006. 631p.

MALAVOLTA, E.; VITTI, G.C. \& OLIVEIRA, S.A. Avaliação do estado nutricional das plantas: Princípios e aplicações. 2.ed. Piracicaba, POTAFOS, 1997. 319p.

MALAVOLTA, E.; NOGUEIRA, N.L.; HEINRICHS, R.; HIGASHI, E.N.; RODRIGUEZ, V.; GUERRA, E.; OLIVEIRA, S.C. \& CABRAL, C.P. Evaluation of nutritional status of the cotton plant with respect to nitrogen. Comm. Soil Sci. Plant Anal., 35:1007-1019, 2004.

MARSCHNER, H. Mineral nutrition of higher plants. 2.ed. London, Academic Press, 1995. 889p.

MATTOS, W.T. \& MONTEIRO, F.A. Produção e nutrição do capim-braquiária em função de doses de nitrogênio e enxofre. B. Ind. Animal, 60:1-10, 2003.

MATTOS, W.T. \& MONTEIRO, F.A. Respostas de Brachiaria brizantha a doses de potássio. Sci. Agric., 55:428-437, 1998.

MEGDA, M.M. Suprimento de nitrogênio e de potássio e características morfogênicas, nutricionais e produtivas do capim-Marandu. Piracicaba, Escola Superior de Agricultura "Luiz de Queiroz", 2009. 84p. (Tese de Mestrado)

MENGEL, K. \& KIRKBY, E. Principles of plant nutrition. 5.ed. Dordrecht/Boston/London, Kluwer Academic, 2001. 849 p.

MINOLTA CAMERA Co. Manual for chlorophyll meter Spad502. Osaka, 1989. 22p.
MULDER, E.G.; BOXMA, R. \& van VENN, W.L. The effect of molybdenum and nitrogen deficiencies on nitrate reduction in plant tissue. Plant Soil, 10:335-355, 1959.

PFLUGER, R. \& WIDEMANN, R. Der einfluss monovalenter kationene auf die nitrate duktion bei Spinacia oleracia L. Z. Pflanzenk. Pflanzen., 85:125-133, 1977.

REIS, A.R.; FAVARIN, J.L.; GALLO, L.A.; MALAVOLTA, E.; MORAES, M.F. \& LAVRES JR., J. Nitrate reductase and glutamine synthetase activity in coffee leaves during fruit development. R. Bras. Ci. Solo, 33:315-324, 2009a.

REIS, A.R.; FAVARIN, J.L.; MALAVOLTA, E.; LAVRES JR., J. \& MORAES, M.F. Photosynthesis, chlorophylls, and SPAD readings in coffee leaves in relation to nitrogen supply. Comm. Soil Sci. Plant Anal., 40:1512-1528, 2009 b.

SARRUGE, J.R. Soluções nutritivas. Summa Phytopathol., 1:231-233, 1975.

SAS Institute. SAS/STAT. User's guide, version 6.11. 4.ed. Cary, Statistical Analysis System Institute, 1996. v.2. 842p.

SILVA JR., M.C.; PINTO, F.A.C.; FONSECA, D.M.; QUEIROZ, D.M. \& MACIEL, B.F. Detecção do efeito da adubação nitrogenada em Brachiaria decumbens Stapf. utilizando um sistema de sensoriamento remoto. R. Bras. Zootec., 37:411-419, 2008.

STROPPIANA, D.; BOSCHETTI, M.; BRIVIO, P.A. \& BOCCHI, S. Plant nitrogen concentration in paddy rice from field canopy hyperspectral radiometry. Field Crop. Res., 111:119-129, 2009.

UMAR, S. \& BANSAL, S.K. Potassium requirement of mustard (Brassica juncea L.) under moisture stress conditions. Plant Physiol. Biochem., 22:130-135, 1995.

VENKATESAN, S. \& GANAPATHY, M.N.K. Nitrate reductase activity in tea as influenced by various levels of nitrogen and potassium fertilizers. Comm. Soil Sci. Plant Anal., 35:1283-1291, 2004.

WERNER, J.C.; PAULINO, V.T.; CANTARELLA, H.; ANDRADE, N.O. \& QUAGGIO, J.A. Forrageiras. In: RAIJ, B.van; CANTARELLA, H.; QUAGGIO, J.A. \& FURLANI, A.M.C., eds. Recomendações de adubação e calagem para o estado de São Paulo. 2.ed. Campinas, Instituto Agronômico de Campinas/Fundação IAC, 1996. p.263-273. (Boletim Técnico, 100)

WIEDENFELD, B.; WALLACE, B.W. \& HONS, F. Indicators of cotton nitrogen status. J. Plant. Nutr., 32:1353-1370, 2009 .

ZHU, Y.; ZHOU, D.; YAO, X.; TIAN, Y. \& CAO, W. Quantitative relationships of leaf nitrogen status to canopy spectral reflectance in rice. Austr. J. Agric. Res., 58:1077-1085, 2007. 